\title{
PCBs and PCDD/Fs in Bluefin Tuna: Occurrence and Dietary Intake
}

\author{
Grazia Barone ${ }^{1}$, Arianna Storelli ${ }^{1}$, Rita Garofalo ${ }^{1}$, Rosanna Mallamaci ${ }^{1}$, Nicoletta C. Quaglia ${ }^{2}$ \\ and Maria Maddalena Storelli ${ }^{1, *}$ (1) \\ 1 Biosciences, Biotechnologies and Biopharmaceutical Department, University of Bari "Aldo Moro", \\ Strada Prov. le per Casamassima Km 3, 70010 Valenzano (Ba), Italy; grazia.barone@uniba.it (G.B.); \\ arianna.storelli@uniba.it (A.S.); rita.garofalo@uniba.it (R.G.); rosanna.mallamaci@uniba.it (R.M.) \\ 2 Department of Emergency and Organ Transplantation, Section of Veterinary Clinic and Animal Production, \\ University of Bari “Aldo Moro”, Strada Prov. le per Casamassima Km 3, 70010 Valenzano (Ba), Italy; \\ nicolettacristiana.quaglia@uniba.it \\ * Correspondence: mariamaddalena.storelli@uniba.it; Tel.: +39-080-544-3866
}

Received: 19 February 2018; Accepted: 27 April 2018; Published: 3 May 2018

\begin{abstract}
Polychlorinated biphenyls (PCBs) and polychlorinated dibenzo-furans (PCDD/Fs) were measured in Mediterranean bluefin tuna (Thunnus thynnus) to verify The compliance with The EU regulations for food commercialization. The estimated intakes were also evaluated. The analyses were performed by gas chromatography-ion trap tandem mass spectrometry (GC-MS-MS). The PCBs were dominant (1132.0 $\mathrm{ng} \mathrm{g}^{-1}$ l.w.), followed by PCDFs (23.2 $\mathrm{pg} \mathrm{g}^{-1}$ l.w.) and PCDDs (8.5 $\mathrm{pg} \mathrm{g}^{-1}$ l.w.). The pollutant levels (dl-PCBs: 0.7 pg TEQ/g w.w.; PCDD/Fs: 1.9 pg TEQ/g w.w.) and their sum expressed as TEQ values (2.6 pg TEQ/g w.w.) remained below The limits for human consumption proposed by The European Union. On The contrary, The sum of The six indicator non-dioxin-like PCBs (84.2 $\mathrm{ng} \mathrm{g}^{-1}$ w.w.) was slightly above The maximum level fixed by The in-force legislation. The estimated dietary intakes for PCDD/Fs plus dl-PCBs were below The toxicological reference values (TRVs) set by various international bodies, while non-cancer and cancer risk assessment revealed a safety concern. Additionally, The estimated intake of ndl-PCBs exceeded The maximum levels set by different European countries. These findings suggest caution in tuna consumption together with an active and frequent surveillance of The chemical quality of its flesh.
\end{abstract}

Keywords: bluefin tuna; estimated dietary intake; PCBs; PCDD/Fs; risk assessment

\section{Introduction}

Polychlorinated dibenzo-p-dioxins (PCDDs) and polychlorinated dibenzo-furans (PCDFs), usually known with The term "dioxins" and polychlorinated biphenyls (PCBs) are a group of halogenated aromatic hydrocarbons exhibiting a high toxic potential. Their toxic action in humans, following chronic exposure, includes carcinogenic potency, immunotoxicity, and a range of negative endocrine effects related to reproduction [1]. The International Agency for Research on Cancer (IARC) classifies 2,3,7,8-TCDD, The most toxic of The dibenzo-p-dioxins together with 2,3,4,7,8-PeCDF and PCB 126 as group 1 carcinogens, meaning "known human carcinogens" [2]. More recently a whole PCB group was classified as carcinogenic for humans [3] too. Due to their characteristics of elevated chemical stability and persistence, these toxicants are present in all environmental media compromising absolutely The "health" of The environment and its biota. The Mediterranean Sea, almost entirely landlocked and with a limited water exchange, constitutes a site surely overexposed to anthropogenic pressure [4-6]. Bluefin tuna, Thunnus thynnus (Linnaeus 1758) is an important species within The Mediterranean ecosystems. Characterized by long lifespan and fast-growth, this top predator of 
The pelagic trophic web is susceptible to contain high concentrations of these lipophilic pollutants $[6,7]$. In addition, Bluefin tuna is a high-performance fish with very elevated metabolic and food intake rates and features enhancing contaminant bioaccumulation [8,9]. There is a well-established evidence that fishery products are one of The main sources of human exposure to these pollutants $[10,11]$. Therefore, The interest and concern about The chemical safety of fishery products has been and still remains a salient point for public opinion [12]. The worldwide food legislation has fixed limits on The concentration of these chemicals in seafood prior to marketing, as well as a relevant number of international regulatory bodies have set up fish consumption guidelines for consumer protection. Moreover, The World Health Organization (WHO) has recommended assessing human exposure to these lipophilic pollutants on a regular basis in order to evaluate either The human health risks or The time trends of exposure and The effectiveness of specific management measures. Consequently, The present study reports The results of congener-specific analysis of PCBs and PCDD/Fs performed on Mediterranean Bluefin-tuna specimens considered one of The most highly valuable fishery resources. In particular, it was verified whether The concentrations of these contaminants match The criteria set by The European Union (EU) regulation for commercialized food [13] or whether The estimated intake level satisfies The standards established by different food safety organizations [13-16].

\section{Materials and Methods}

\subsection{Sample Collection}

Twenty-six specimens of Thunnus thynnus (Bluefin tuna) (12 males and 14 females) were caught in The Southwestern Mediterranean Sea (FAO area 37.1) (Figure 1). Approximately 0.1-0.3 kg of muscle tissue was removed from The anterior portion of The carcass by a transverse dissection near The dorsal fin. These muscle portions were homogenized and kept in a deep freeze at $-20^{\circ} \mathrm{C}$ until chemical analysis. The sampling methodology used was in accordance with The European Commission Regulation [17]. The biological data of each fish were recorded (Table 1). The fish age and maturity stage were estimated according to Rodriguez-Roda [18] and Corriero et al. [19], respectively. The fish condition (K) was calculated using Fulton's coefficient: $K=W / L^{3} \times 100$ [20], where $W$ is wet weight (g) and $\mathrm{L}$ total length $(\mathrm{cm})$.

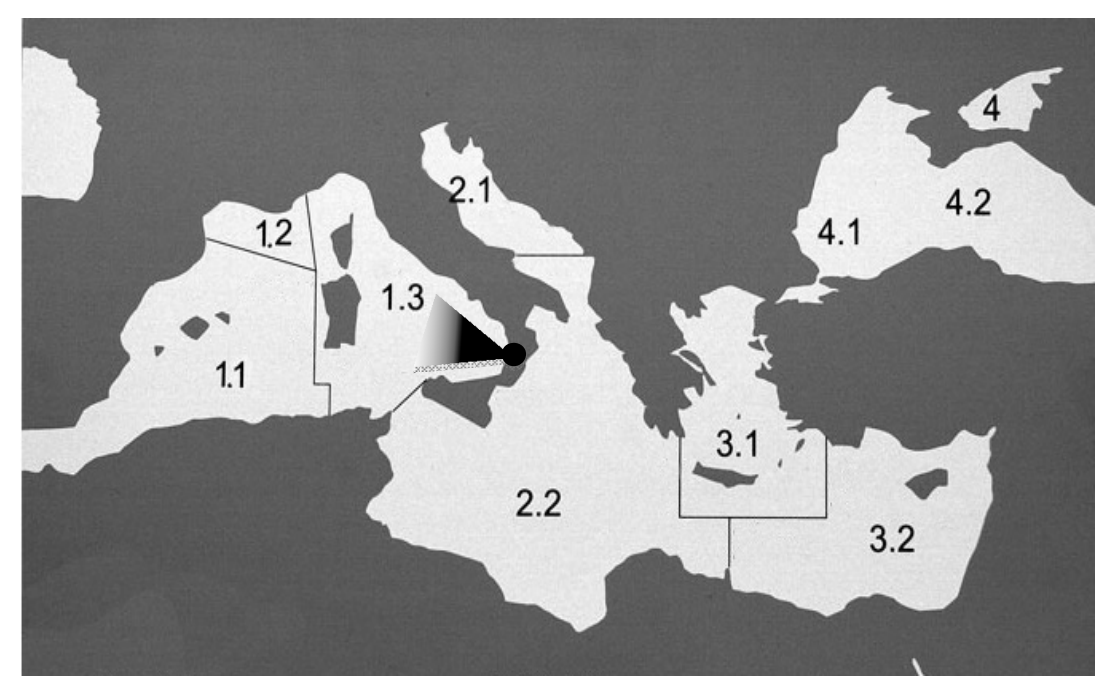

Figure 1. The sampling area: Food and Agriculture Organization (FAO) fishing area 37; division 37.1.3. 
Table 1. The biological data of The Bluefin tunas examined.

\begin{tabular}{|c|c|c|c|c|c|c|}
\hline Tunas No. & Sex & $\begin{array}{c}\text { Body Weight } \\
\text { (kg) }\end{array}$ & $\begin{array}{l}\text { Body Length } \\
\text { (cm) }\end{array}$ & $\begin{array}{l}\text { Condition } \\
\text { (K) }{ }^{1}\end{array}$ & $\begin{array}{l}\text { Estimated Age } \\
\text { (years) }{ }^{2}\end{array}$ & Maturity $^{3}$ \\
\hline 1 & F & 18 & 107 & 1.47 & 2 & Juvenile \\
\hline 2 & M & 30 & 115 & 1.97 & 4 & Juvenile \\
\hline 3 & $\mathrm{M}$ & 28 & 120 & 1.62 & 3 & Juvenile \\
\hline 4 & $\mathrm{M}$ & 35 & 120 & 2.03 & 3 & Juvenile \\
\hline 5 & $\mathrm{~F}$ & 38 & 123 & 2.04 & 4 & Juvenile \\
\hline 6 & $\mathrm{M}$ & 40 & 127 & 1.95 & 4 & Juvenile \\
\hline 7 & F & 43 & 129 & 2.00 & 4 & Juvenile \\
\hline 8 & F & 45 & 130 & 2.05 & 4 & Juvenile \\
\hline 9 & $\mathrm{~F}$ & 43 & 131 & 1.91 & 4 & Juvenile \\
\hline 10 & F & 51 & 133 & 2.17 & 4 & Juvenile \\
\hline 11 & F & 50 & 135 & 2.03 & 4 & Juvenile \\
\hline 12 & F & 50 & 135 & 2.03 & 4 & Juvenile \\
\hline 13 & F & 50 & 135 & 2.03 & 4 & Juvenile \\
\hline 14 & M & 56 & 140 & 2.04 & 5 & Adult \\
\hline 15 & $\mathrm{M}$ & 56 & 140 & 2.04 & 5 & Adult \\
\hline 16 & M & 56 & 140 & 2.04 & 5 & Adult \\
\hline 17 & $\mathrm{~F}$ & 64 & 143 & 2.19 & 5 & Adult \\
\hline 18 & F & 51 & 143 & 1.74 & 5 & Adult \\
\hline 19 & F & 54 & 144 & 1.81 & 5 & Adult \\
\hline 20 & $\mathrm{~F}$ & 50 & 147 & 1.57 & 5 & Adult \\
\hline 21 & F & 69 & 150 & 2.04 & 5 & Adult \\
\hline 22 & $\mathrm{M}$ & 69 & 150 & 2.04 & 5 & Adult \\
\hline 23 & $\mathrm{M}$ & 76 & 155 & 2.04 & 5 & Adult \\
\hline 24 & $\mathrm{M}$ & 93 & 172 & 1.83 & 6 & Adult \\
\hline 25 & M & 102 & 178 & 1.81 & 7 & Adult \\
\hline 26 & $\mathrm{M}$ & 161 & 218 & 1.55 & 10 & Adult \\
\hline
\end{tabular}

\subsection{Chemical and Instrumental Analyses}

All reagents and solvents were of analytical grade and were purchased from Merck (Darmstadt, Germany). The glassware was obtained from Levanchimica (Bari, Italy). PCB and PCDD/F standards were purchased from Wellington Laboratories (Guelph, Ontario, Canada). Eighteen individual PCB congeners (indicator non-dioxin-like PCBs (ndl-PCBs): 28, 52, 101, 138, 153, and 180 and dioxin-like PCBs (dl-PCBs): non-ortho PCBs 77, 81, 126, 169 and mono-ortho PCBs 105, 114, 118 123, 156, 157, $167,189)$ and The seventeen 2,3,7,8-substituted PCDD/F congeners were quantified. A complete description of The experimental procedures relative to PCBs and PCDD/Fs has been described and validated elsewhere [21]. Approximately, $0.5 \mathrm{~g}$ of homogenized fish tissue was crushed in a mortar along with anhydrous sodium sulfate. The internal standard PCB 143 was added to The melted sample. The mixture extracted with hexane was concentrated under a gentle nitrogen stream. A gravimetric method was used to determine The percentage of fat in subsamples of The extract. At about $100 \mathrm{mg}$ of The residual extract dissolved in hexane was applied to a silica clean-up column ( $8 \mathrm{~g}$ of acid silica in $\mathrm{H}_{2} \mathrm{SO}_{4}, 44 \%$ wet weight $1 / 1, v / v$ ) and eluted with $50 \mathrm{~mL}$ of a mixture of hexane/dichloromethane. After evaporation to dryness, $100 \mu \mathrm{L}$ of iso-octane was added to The eluate and The sample was put into a GC-MS vial. The determination of PCDD/Fs was based on The US EPA method 1613. The samples were extracted with The method reported above and a multistep cleanup technique was undertaken to remove The matrix and The potential interfering components. The extract was first subjected to The action of The sulfuric acid to destroy The bulk of The fat and subsequently to a base back-extraction technique. The solution was then loaded onto a pre-conditioned florisil clean-up column and eluted with The appropriate solutions in order to remove The interfering components. The purified eluate containing PCDD/Fs was collected, concentrated, and fortified with appropriate $\mathrm{C}^{13}$-labeled extraction standards and transferred into a GC-MS vial. Finally, these obtained PCB and PCDD/F extracts were injected and analyzed separately on a Thermo Trace GC connected with a 
Thermo PolarisQ MS (Thermo Fisher Scientific, Waltham, MA, USA) operated in electron impact ionization (EI) mode. The chromatographic separation was attained by split-less injection on a capillary column with length of $30 \mathrm{~m}$, i.d. $0.25 \mathrm{~mm}$, and $0.25 \mu \mathrm{m}$ thickness stationary phase film (RTX-5, Restek, US, Bellefonte, PA, USA) for PCBs, while for PCDD/Fs a capillary column with a length of $30 \mathrm{~m} \times 0.25 \mathrm{~mm}$ and $0.25 \mu \mathrm{m}$ thickness stationary phase film (RTX-200 Restek, US, Bellefonte, PA, USA) was employed. The MS was used in The SIM mode with The two most intensive ions of The molecular ion cluster monitored in specific windows for PCBs. PCDD/Fs quantification was archived using The ion trap in MS/MS mode and following The isotopic dilution method in accordance with US EPA 1613. The optimized parameters are shown in Table 2.

Table 2. The optimized tandem mass spectrometry (MS/MS) parameters for The analysis of polychlorinated dibenzo-furans (PCDD/Fs) in gas chromatography mass spectrometry (GC/MS) PolarisQ used in MS/MS mode.

\begin{tabular}{ccccc}
\hline Compound & & Precusor Ions $(\mathbf{m} / \boldsymbol{z})$ & Excitacion Voltage $(\mathbf{V})$ & Product Ions $(\mathbf{m} / \mathbf{z})$ \\
\hline \multirow{2}{*}{ TCDF } & ${ }^{12} \mathrm{C}$ & 306.0 & 4.75 & $241-243$ \\
& ${ }^{13} \mathrm{C}$ & 318.0 & 4.75 & $252-254$ \\
\hline \multirow{2}{*}{ TCDD } & ${ }^{12} \mathrm{C}$ & 322.0 & 4.4 & $257-259$ \\
& ${ }^{13} \mathrm{C}$ & 334.0 & 4.4 & $268-270$ \\
\hline \multirow{2}{*}{ PeCDFs } & ${ }^{12} \mathrm{C}$ & 340.0 & 5.05 & $275-285$ \\
& ${ }^{13} \mathrm{C}$ & 352.0 & 5 & $286-288$ \\
\hline \multirow{2}{*}{ PeCDD } & ${ }^{12} \mathrm{C}$ & 355.9 & 4.4 & $291-293$ \\
& ${ }^{13} \mathrm{C}$ & 367.9 & 4.3 & $302-304$ \\
\hline \multirow{2}{*}{$\mathrm{HxCDFs}$} & ${ }^{12} \mathrm{C}$ & 373.9 & 5.3 & $318-322$ \\
& ${ }^{13} \mathrm{C}$ & 385.9 & 5.2 & $327-330$ \\
\hline \multirow{2}{*}{$\mathrm{HxCDDs}$} & ${ }^{12} \mathrm{C}$ & 389.9 & 4.4 & $323-324$ \\
& ${ }^{13} \mathrm{C}$ & 401.9 & 4.5 & $333-334$ \\
\hline \multirow{2}{*}{$\mathrm{HpCDFs}$} & ${ }^{12} \mathrm{C}$ & 407.9 & 5.5 & $345-347$ \\
& ${ }^{13} \mathrm{C}$ & 419.0 & 5.3 & $358-360$ \\
\hline \multirow{2}{*}{$\mathrm{HpCDDs}$} & ${ }^{12} \mathrm{C}$ & 423.9 & 4.5 & $361-363$ \\
& ${ }^{13} \mathrm{C}$ & 435.8 & 4.6 & $368-380$ \\
\hline OCDF & ${ }^{12} \mathrm{C}$ & 443.7 & 5.5 & $375-378$ \\
\hline \multirow{2}{*}{ OCDD } & ${ }^{12} \mathrm{C}$ & 459.7 & 4.9 & $395-397$ \\
\hline${ }^{13} \mathrm{C}$ & 471.8 & 4.85 & $403-408$ \\
\hline
\end{tabular}

\subsection{Quality Assurance and Quality Control}

The quality control and quality assurance protocols included analysis of procedural blanks, duplicate samples, and The use of standard reference materials (CRM 349 for PCBs (cod liver oils) (BCR, Brussels) and CARP-2 for PCDD/Fs (NRCC) (IRMM, Geel, Belgium)) for each set of samples. For The replicate and standard reference materials, The relative standard deviations (RSD) were $<10 \%$ for all The detected compounds. Moreover, The laboratory ability for measurements of The PCBs was validated in inter-laboratory trials organized by QUASIMEME (Laboratory Performance Studies). The results obtained were within a range of $20 \%$ from The consensus values. The multi-level calibration curves $\left(r^{2}>0.999\right)$ in The linear response interval of The detector were built in order to result in a range of 2-10,000 $\mathrm{ng} \mathrm{g}^{-1}$ lipid weight for PCB 153, PCB 138 and PCB 180, in a range of 2-2000 $\mathrm{ng} \mathrm{g}^{-1}$ lipid weight for The other PCB congeners and in a range of 0.02-2000 $\mathrm{ng} \mathrm{g}^{-1}$ lipid weight for PCDD/Fs. The relative retention times (RRTs) of each analyte did not differ by more than $\pm 0.5 \%$ of The RRTs of The internal standards used for quantification, ion chromatograms and intensity ratios of The monitored ions. The relative intensities of The detected ions, expressed as a percentage of The intensity of The most abundant ion, were within $20 \%$ of The mean values obtained 
for calibration standards. All The procedural blanks were subjected to same processes of The samples and no measurable quantities of target compounds were detected. The limits of detection (LODs) were calculated as three times The signal-to-noise ratio and varied amongst analyte groups $\left(00.1-0.26 \mathrm{pg} \mathrm{g}^{-1}\right.$ for PCDD/Fs and 0.01-0.40 $\mathrm{ng} \mathrm{g}^{-1}$ lipid weight for PCBs). Concentrations of PCBs and PCDD/Fs are presented as $\mathrm{ng} \mathrm{g}^{-1}$ on a lipid weight basis and $\mathrm{pg} \mathrm{g}^{-1}$ on a lipid weight basis, respectively. For comparative purposes, TEQ concentrations are expressed in pg TEQ $\mathrm{g}^{-1}$ wet weight.

\subsection{Exposure Assessment}

The estimated dietary intakes of PCDD/Fs plus dl-PCBs were calculated by multiplying The pelagic fish consumption data ( $85 \mathrm{~g} /$ week) [22] by The mean concentrations in tuna and then dividing by The body weight $(70 \mathrm{~kg})$ using The following equation:

$$
\mathrm{Y}=\mathrm{C} \times \mathrm{X} / \mathrm{bw}
$$

where $\mathrm{C}$ is The sum of PCDD/F plus dl-PCB levels express as TEQ (pg TEQ $\mathrm{g}^{-1}$ wet weight), $\mathrm{X}$ is The consumption quantity of that particular item by an individual ( $\mathrm{g}$ wet weight), and bw is The body weight of The individual. The TEQ concentrations were calculated by multiplying The individual congener concentrations by their respective toxic equivalency factors (TEFs), as established by The World Health Organization (WHO) in 2005 [23] and subsequently summed up to give The total concentrations. Non detected congeners were considered equal to zero (lower bound estimates). Risk-based consumption limits for non-cancer and cancer health endpoints, concerning PCBs and PCDD/Fs, were calculated using The EPA [24] developed fish consumption limit tables (Table 3). The variables used to calculate The fish consumption limits included The consumer body weight $(70 \mathrm{~kg})$, time-averaging period selected (monthly), fish meal size (227 $\mathrm{g}$ of cooked filet), number of monthly meals, and reference contaminant concentration ranges in The fish tissue calculated following The USEPA Integrated Risk Information System (IRIS).

\subsection{Statistical Analysis}

The Kruskal-Wallis test was conducted to verify The difference in The levels of PCB and PCDD/F accumulation, while The simple linear regression coefficient was used to examine The correlations between PCBs and specimen length. In order to investigate The influence of The size on PCB accumulation, The length of fish was chosen because it is less subject to fluctuation than body weight [25]. The level of significance was set at $p<0.05$.

Table 3. The monthly fish consumption limits for carcinogenic and non-carcinogenic health endpoints ${ }^{1}$.

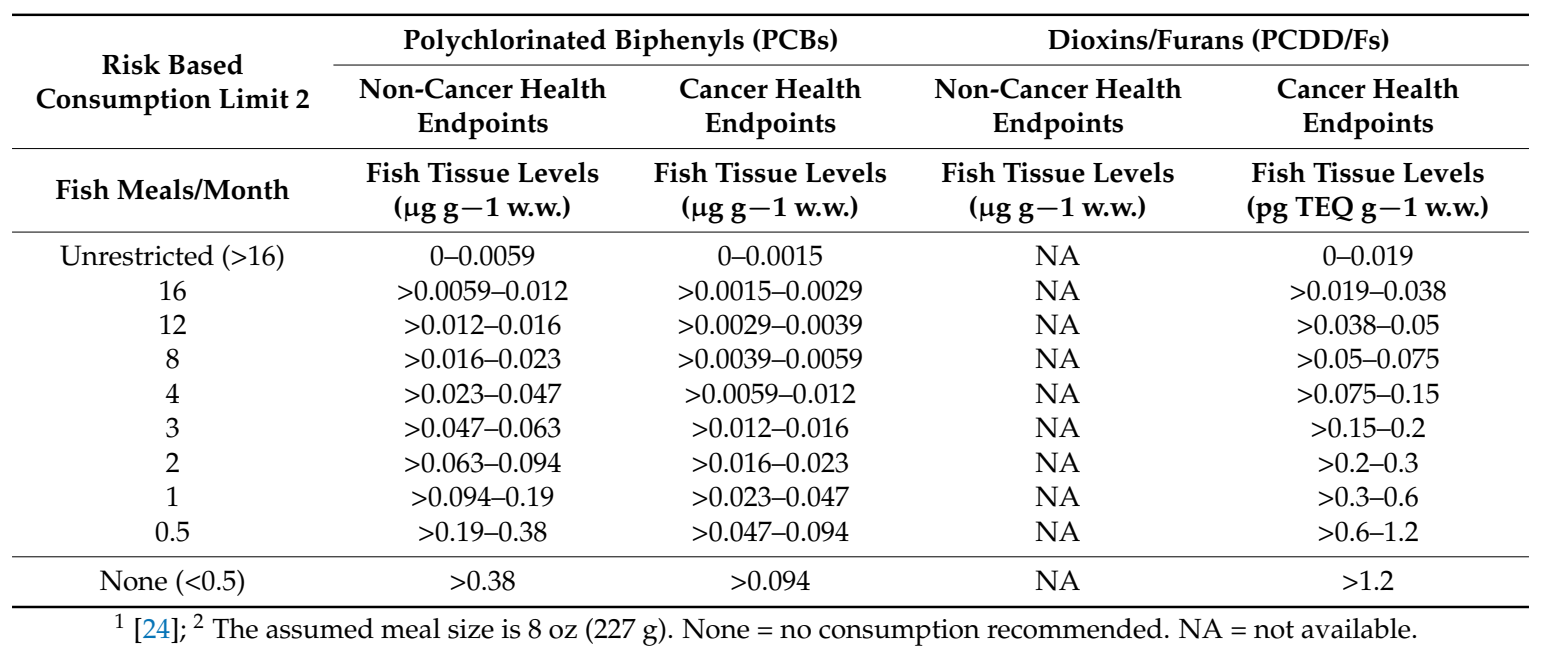




\section{Results and Discussion}

\subsection{Concentrations and Congener Profiles of ndl-PCBs, dl-PCBs, and PCDD/Fs}

The chemical analysis results of PCBs and PCDD/Fs together to detection frequency for each congener are illustrated in Table 4. As revealed by statistical analysis, PCBs were more abundant (range: 237.7-6673.5 $\mathrm{ng} \mathrm{g}^{-1}$ lipid weight; mean: $1132.0 \mathrm{ng} \mathrm{g}^{-1}$ lipid weight) than The PCDD/F group (PCDD/Fs range: $5.3-70.1 \mathrm{pg} \mathrm{g}^{-1}$ lipid weight; mean: $31.7 \mathrm{pg} \mathrm{g}^{-1}$ lipid weight; PCDFs range: 2.7-67.5 $\mathrm{pg} \mathrm{g}^{-1}$ lipid weight; mean $23.2 \mathrm{pg} \mathrm{g}^{-1}$ lipid weight; PCDDs range: ND-18.1 $\mathrm{pg} \mathrm{g}^{-1}$ lipid weight; mean: $8.5 \mathrm{pg} \mathrm{g}^{-1}$ lipid weight $(p<0.001)$ and no significant difference in The PCB and PCDD/F contamination level was observed between males and females $(p>0.05)$.

Table 4. The polychlorinated biphenyls (PCBs) (ng $\mathrm{g}^{-1}$ lipid weight) and The PCDD/Fs ( $\mathrm{pg} \mathrm{g}^{-1}$ lipid weight) concentrations and occurrence in Bluefin tuna from The Mediterranean Sea.

\begin{tabular}{|c|c|c|c|}
\hline Congener & Min-Max & Mean \pm St. Dev. & $\%$ Occurrence \\
\hline \% Lipid & $10.2-40.2$ & $19.0 \pm 12.6$ & - \\
\hline $\begin{array}{c}\text { ndl-PCBs } \\
\text { PCB } 28\end{array}$ & ND & ND & - \\
\hline PCB 52 & ND-87.8 & $13.2 \pm 17.9$ & 80.8 \\
\hline PCB 101 & ND-590.6 & $90.6 \pm 138.0$ & 96.2 \\
\hline PCB 138 & 60.9-1730.1 & $283.5 \pm 389.1$ & 100.0 \\
\hline РCB 153 & 93.2-2501.6 & $430.5 \pm 605.7$ & 100.0 \\
\hline PCB 180 & $29.4-1132.0$ & $164.3 \pm 258.7$ & 100.0 \\
\hline$\Sigma$ ndl-PCBs & $209.8-6042.2$ & $982.1 \pm 1041.0$ & - \\
\hline $\begin{array}{c}\sum \text { ndl-PCBs }{ }^{1} \\
\text { dl-PCBs }^{2}\end{array}$ & $3.4-219.3$ & $84.2 \pm 64.3$ & - \\
\hline \multicolumn{4}{|l|}{ Non-ortho PCBs } \\
\hline PCB 77 & ND-0.04 & $0.01 \pm 0.01$ & 46.2 \\
\hline РCВ 81 & ND & ND & - \\
\hline PCB 126 & ND-0.05 & $0.01 \pm 0.02$ & 19.2 \\
\hline PCB 169 & ND & ND & - \\
\hline \multicolumn{4}{|l|}{ Mono-ortho PCBs } \\
\hline PCB 105 & ND-25.7 & $3.0 \pm 6.5$ & 23.1 \\
\hline РCB 114 & ND-9.4 & 5. $0 \pm 3.1$ & 80.8 \\
\hline PCB 118 & $22.7-528.9$ & $92.2 \pm 116.8$ & 100.0 \\
\hline PCB 123 & ND-30.8 & $12.4 \pm 8.5$ & 88.5 \\
\hline PCB 156 & ND-100.0 & $33.3 \pm 31.6$ & 61.5 \\
\hline PCB 157 & ND-9.5 & $4.0 \pm 3.7$ & 57.7 \\
\hline PCB 167 & ND & ND & - \\
\hline PCB 189 & ND & ND & - \\
\hline$\Sigma$ dl-PCBs & $22.7-631.3$ & $149.9 \pm 145.3$ & - \\
\hline$\Sigma \mathrm{dl}^{-\mathrm{PCBs}}{ }^{1}$ & $0.9-46.6$ & $17.4 \pm 12.5$ & - \\
\hline$\Sigma$ ndl-PCBs + dl-PCBs & $237.7-6673.5$ & $1132.0 \pm 1543.5$ & - \\
\hline$\sum$ ndl-PCBs + dl-PCBs ${ }^{1}$ & $5.1-265.8$ & $101.5 \pm 76.9$ & - \\
\hline \multicolumn{4}{|l|}{ Dioxins } \\
\hline $2,3,7,8-\mathrm{TCDD}$ & ND-6.0 & $2.1 \pm 1.7$ & 80.8 \\
\hline $1,2,3,7,8-\mathrm{PeCDD}$ & ND-9.6 & $3.7 \pm 4.6$ & 42.3 \\
\hline 1,2,3,4,7,8-HxCDD & ND-6.0 & $1.4 \pm 2.3$ & 42.3 \\
\hline $1,2,3,6,7,8-\mathrm{HxCDD}$ & ND & ND & - \\
\hline $1,2,3,7,8,9-\mathrm{HxCDD}$ & ND & ND & - \\
\hline 1,2,3,4,6,7,8-HpCDD & ND-2.0 & $0.6 \pm 0.9$ & 38.5 \\
\hline OCDD & ND-1.6 & $0.7 \pm 0.6$ & 61.5 \\
\hline$\Sigma$ PCDDs & $1.0-18.1$ & $8.5 \pm 5.7$ & - \\
\hline$\Sigma$ PCDDs $^{1}$ & $0.02-4.1$ & $1.5 \pm 1.3$ & - \\
\hline \multicolumn{4}{|l|}{ Furans } \\
\hline $2,3,7,8-\mathrm{TCDF}$ & ND-27.0 & $9.2 \pm 9.4$ & 69.2 \\
\hline 1,2,3,7,8-PeCDF & ND-6.9 & $2.4 \pm 2.2$ & 61.5 \\
\hline $2,3,4,7,8-\mathrm{PeCDF}$ & ND-25.3 & $8.2 \pm 9.8$ & 50.0 \\
\hline $1,2,3,4,7,8-\mathrm{HxCDF}$ & ND-4.8 & $0.7 \pm 1.6$ & 26.9 \\
\hline $1,2,3,6,7,8-\mathrm{HxCDF}$ & ND-10.4 & $2.2 \pm 3.6$ & 34.6 \\
\hline 1,2,3,7,8,9-HxCDF & ND & ND & - \\
\hline 2,3,4,6,7,8-HxCDF & ND & ND & - \\
\hline $1,2,3,4,6,7,8-\mathrm{HpCDF}$ & ND & ND & - \\
\hline
\end{tabular}


Table 4. Cont.

\begin{tabular}{cccc}
\hline Congener & Min-Max & Mean \pm St. Dev. & \% Occurrence \\
\hline $1,2,3,4,7,8,9-\mathrm{HpCDF}$ & $\mathrm{ND}$ & $\mathrm{ND}$ & - \\
OCDF & ND-2.5 & $0.4 \pm 0.9$ & 23.1 \\
$\Sigma \mathrm{PCDFs}$ & $2.7-67.5$ & $23.2 \pm 20.3$ & - \\
$\Sigma \mathrm{PCDFs}{ }^{1}$ & $0.01-24.9$ & $5.0 \pm 6.8$ & - \\
$\Sigma \mathrm{PCDD} / \mathrm{Fs}$ & $5.3-70.1$ & $31.7 \pm 19.3$ & - \\
$\Sigma \mathrm{PCDD} / \mathrm{Fs}{ }^{1}$ & $0.06-26.2$ & $6.7 \pm 7.0$ & - \\
\hline & ${ }^{1} \mathrm{ng} \mathrm{g}^{-1}$ : wet weight; ND: not detected.
\end{tabular}

Regarding The detection frequency, congeners PCBs 138, 153, 180, and 118 occurred in all The examined samples, PCBs 52,101, 114, and 123 were quantified in over than $80 \%$ of The samples, PCBs 77, 156, and 157 showed a detection frequency between $46.2 \%$ and $61.5 \%$, while The rarest were PCBs 105 and 126 detected in $23.1 \%$ and $19.2 \%$ of The samples, respectively. The remaining PCBs $(28,81,167,169$ and 189) were absent in all The samples tested. PCBs 153 (38.0\%) and 138 $(25.0 \%)$ were The most prominent congeners, followed by PCB 180 (14.5\%), PCBs 101 and 118 which gave an almost equal contribution (8.0-8.1\%), while congeners PCBs 52, 77, 105, 114, 123, 126, 156, and 157 collectively constituted a small fraction of The total (6.3\%). A recent investigation on persistent organic pollutants in albacore tunas reported gender-related differences on The PCB profile [26]. A predominance of tri-to pentachlorinated congeners was observed in females, while males showed a higher contribution of hexa-to heptachlorinated PCBs [26]. In our case no variation in The isomeric classes of PCBs was observed, having both sexes a coincident fingerprint with a higher contribution of The middle chlorinated congeners $(84.2 \%)$, followed by hepta-chlorine substituted PCB $180(14.5 \%)$, while The low-chlorinated congeners made up a very small quota of The total PCBs (1.2\%). This profile is coherent with that presented in various studies not only for tunas [7,10,26-28] but also for other fish [29,30] and marine mammals [31]. The predominance of The middle chlorinated congeners as well as The hepta-chlorine substituted PCB 180 occurs as a result of their stability because chlorine atoms in The 2,4,5-positions in one or both rings are particularly resistant to metabolic degradation by cytochrome P450 iso-enzymes [32], while The moderate presence of lower chlorinated PCBs has, generally, been explained by The elevated exchange rate of these congeners with The environment through The gills [27]. However, besides The physico-chemical properties of these compounds, a multitude of other ecological and biological factors, including The health conditions of animals, feeding habits, reproductive strategies, age, and size may control PCB accumulation. A rising bio-accumulation with The increasing of size has been noted many times in various marine organisms, including also tunas $[5,8]$. In this investigation no significant relationship was found between PCB concentrations and fish length, either considering sexes together $(R=0.17$; $p>0.05$ ) or separately (females: $R=0.10 ; p>0.05$; males: $R=0.26 ; p>0.05$ ). The absence of such a correlation may be explained by a growth dilution effect of contaminant load with increased size or age, reported above all in organisms such as tunas, which have a faster growth rate than The accumulation rate $[33,34]$. Additionally, reproduction may significantly influence The concentrations of these contaminants. At The beginning of The reproductive period, adult tunas use their stored lipids as an energy reservoir to produce gametes and consequently stored lipids in muscle decrease, leading to a loss of these lipophilic chemicals [26]. Different maturity stages of specimens here analyzed (see Table 1) might, thus, be The cause of The absence of PCB concentration/length relationships. In regards to The indicator ndl congeners, The relative concentrations ranged between 209.8 and $6042.2 \mathrm{ng} \mathrm{g}^{-1}$ lipid weight, with a mean value of $982.1 \mathrm{ng} \mathrm{g}^{-1}$ lipid weight, and their sum represented more than $85.0 \%$ of The total measured PCB concentration. In terms of The contribution to The total ndl-PCB levels, hexachlorobiphenyl PCB 153 was The most prevalent congener, accounting for $43.8 \%$ in good correspondence with what was reported in other surveys, demonstrating that PCB 153 has an average contribution of roughly one third to The sum of The six indicators [35,36]. The next dominant 
congener was PCB 138 constituting 28.9\%, followed by PCB 180 making 16.7\% and by PCBs 101 and 52 representing $9.2 \%$ and $1.3 \%$, of The total burden respectively. The prevalence of congeners 138 and 153 is consistent with their chemical features as these molecules are less hydrophobic and not so tightly bound to sediment than higher chlorinated octa-deca-PCBs, The reason why they are more readily available to water organisms [37]. Concerning The $12 \mathrm{dl}-\mathrm{PCBs}$, The levels were within The lipid weight range of 22.7-631.3 $\mathrm{ng} \mathrm{g}^{-1}$ (mean: $149.9 \mathrm{ng} \mathrm{g}^{-1}$ lipid weight) and represented $13.2 \%$ of The total PCBs. Mono-ortho PCBs constituted more than $99.0 \%$ of dl-PCB levels. Of these PCBs, The congeners 118 (61.5\%) and 156 (22.2\%) were analytically predominant, followed by PCB $123(8.3 \%)$, PCB $114(3.3 \%)$, PCB $157(2.7 \%)$, and PCB 105 (2.0\%), which accounted for moderate percentages, while The coplanar non-ortho chlorine substituted PCBs 77 and 126 gave a negligible contribution $(0.01 \%)$ to The total concentration of dl-PCBs. These findings are in accordance with other studies which report as predominant homolog group The pentachlorobiphenyls among dl-PCB, and in particular of PCB 118 not only in tunas $[10,26,28,38]$ but also in other fish $[30,38]$. With respect to PCDD/Fs, The contribution of furans $(70.9 \%)$ was higher than that of dioxins $(29.1 \%)$, constituting more than twice in The total concentrations of PCDD/Fs $(p<0.01)$. The congeners that were detected more were 2,3,4,7-TCDD, 2,3,7,8-TCDF, 1,2,3,7,8-PeCDF, OCDD, and 2,3,4,7,8-PeCDF, having a detection frequency equal or above $50.0 \%$. The other PCDD/F congeners quantified in more moderate amounts were 1,2,3,7,8-PeCDD (42.3\%), 1,2,3,4,7,8-HxCDD (42.3\%), 1,2,3,4,6,7,8-HpCDD (38.5\%), 1,2,3,6,7,8-HxCDF $(34.6 \%), 1,2,3,4,7,8-\operatorname{HxCDF}(26.9 \%)$, and OCDF $(23.1 \%)$, while The remaining ones were absent in all The samples examined. The profile of homologues was dominated by The tetra- to hexa-substituted PCDD/F congeners, whose combined levels accounted for more than $90.0 \%$ of all PCDD/Fs, while OCDD and OCDF constituted $3.6 \%$ and hepta-substituted PCDD/F congeners accounted for a small percentage of The total, representing $1.9 \%$. It is not surprising that The lower substituted PCDD/F congeners dominated in The analyzed fish samples. In line with what was reported in The literature, The congener pattern changes in The food chain with The lower-chlorinated congeners dominating in species on The top trophic levels, including either marine mammals [39] or large predator fish such as tunas [40] and sharks [41]. This may be attributable to The limited biomagnification of higher chlorinated congeners along The food webs [42].

\subsection{Compliance with European Union Legislation}

Owing to The potential health risks of these substances, The maximum levels in fishery products have been established by various government agencies worldwide. European legislation has fixed The maximum levels of these contaminants, which are regularly updated according to The advances in scientific knowledge. The maximum levels for PCDD/Fs and PCDD/Fs plus dl-PCB compounds in seafood are set by European Union (EU) directive No 1259/2011 [13] and these levels cannot exceed a wet weight of 3.5 and $6.5 \mathrm{pg} \mathrm{g}^{-1}$ of toxic equivalents (WHO-TEQ), respectively. Moreover, The same regulation has set de novo a maximum level for The sum of The six ndl-PCBs in seafood, that is, a wet weight o f75 $\mathrm{ng} \mathrm{g}^{-1}$, apart from some exceptions [13]. These different levels are necessary because The various PCB congeners exert their toxic effects via different mechanisms. In particular, PCBs may possess a dioxin-like PCBs or a non-dioxin-like PCBs activity. The $12 \mathrm{dl}-\mathrm{PCB}$ congeners share The same mechanism of action with The 17 toxic PCDD/Fs, whereby The effects are mediated through a specific cytoplasmic receptor protein, The aryl hydrocarbon (Ah) receptor [35]. The non-dioxin-like PCB group, including The six indicator congeners, appears to act via different modes exerting their toxicity primarily on neuronal cells with The reduction of dopamine neurotransmitter levels and interference with calcium homeostatis $[43,44]$. These congeners are less toxic than dl-PCBs, though they present a risk level not only due to their complex spectrum of adverse neurological effects, but also because of their presence as mixtures at higher concentrations in biotic and abiotic matrices [45,46]. In particular, The indicator congeners represent approximately half of The total non-dioxin-like PCBs existing in dietary products, and hence, have been recommended by The European Food Safety Authority (EFSA) Scientific Panel regarding Contaminants in The Food Chain (CONTAM Panel) as an appropriate marker 
of PCB contamination levels in food [35]. In The present study, The sum of The indicator ndl-PCB concentrations, given in wet weight $\left(84.2 \mathrm{ng} \mathrm{g}^{-1}\right.$ wet weight) to allow The comparison with The EU legislation, was slightly above The maximum level ( $75 \mathrm{ng} \mathrm{g}^{-1}$ wet weight) in many cases. In detail, 16 specimens displayed levels not compliant and of these, solely three presented concentrations close to The critical value. For The remaining 10 samples, The values were lower than The maximum level relative to marketing. On The contrary, The dl-PCB and PCDD/F level and their sum, expressed as TEQ values on a wet weight basis, remained lower than The maximum level fixed by The European Union's (EU) regulations for food commercialization, being $0.7 \mathrm{pg} \mathrm{TEQ} \mathrm{g}^{-1}$ wet weight, $1.9 \mathrm{pg}$ TEQ $\mathrm{g}^{-1}$ wet weight and $2.6 \mathrm{pg}^{\mathrm{T}}$ TEQ $\mathrm{g}^{-1}$ wet weight, respectively.

\subsection{Dietary Exposure Estimate}

Fish consumption is a relevant source of polyunsatured fatty acids from The n-3 family, which are known to have a beneficial impact on human health by reducing The risk of coronary disease [47]. The American Heart Association (AHA) recommends consuming at least two 3 (2-85 g) oz portion of fish, especially fatty fish, weekly [48]. Nevertheless, The consumption of contaminated fish is one of The relevant pathways for The transfer of these contaminants from The environment to humans [49]. Consequently, The World Health Organization (WHO) sets toxicological reference values (TRVs) such as a tolerable daily intake (TDI) of 1-4 pg WHO-TEQ $\mathrm{g}^{-1}$ body weight day ${ }^{-1}$ for PCDD/F plus dl-PCBs [14], while The European Scientific Committee on Food (SCF) defines a tolerable weekly intake level (TWI) to which humans can be exposed without harm to $14 \mathrm{pg}$ WHO-TEQ $\mathrm{kg}^{-1}$ body weight [16]. Likewise, The Joint FAO/WHO Expert Committee on Food Additives [15] sets a provisional tolerable monthly intake (PTMI) of $70 \mathrm{pg}$ WHO-TEQ $\mathrm{kg}^{-1}$ body weight month ${ }^{-1}$. In reference to these doses, The estimated mean intakes of PCDD/Fs plus dl-PCBs (EDI: $12.5 \%$ of TRV; EWI: $22.8 \%$ of TRV) were lower than The tolerable maximum levels. Additionally, The probabilistic P50, P75, and P95 intake estimates showed values of 2.6, 5.2, and 7.4 $\mathrm{pg}$ WHO/TEQ $\mathrm{kg}^{-1}$ bw per week, respectively. These values, being lower than $14 \mathrm{pg}$ WHO/TEQ $\mathrm{kg}^{-1}$ bw computed by SCF, indicated that The dietary consumption of these marine products does not implicate an appreciable human health risk. Nevertheless, these results must be interpreted cautiously when we are thinking in terms of The risk for humans because The estimate intakes are point estimates, whereas The reference limits are defined for one's life-long intake [50]. With regard to The non-cancer and cancer risks for The ingestion of PCBs and PCDD/Fs, The EPA guideline [24] presents data for The limits of fish consumption based on an exposure for a period of 70 years. Through The use of a so-called cancer slope factor (CSF) that considers The appearance of one new case of cancer for every 100,000 individuals significant, The EPA developed fish consumption limit tables that take into consideration both chronic and carcinogenic effects [24] (Table 3). On this basis, The monthly limit for tuna consumption was 1 portion of $227 \mathrm{~g}$ to avoid any carcinogenic risk for both contaminants, while no criticism was observed concerning to The noncancer risk for PCDD/Fs considering The value of reference (RfD: $0.7 \mathrm{pg} / \mathrm{kg}$ bw $\times$ day) derived by USEPA [51]. Similarly, no noncancer risk was evident for PCBs too, even though it is necessary to underline that The reference dose for chronic exposure set by EPA was fixed for Aroclor 1254 and not for PCB group analyzedhere, which might pose a larger risk. However, because it appears that it is safe to consume up to 8 meals/month The non-cancer risk was negligible. Concerning non-dioxin-like PCBs, The European Food Safety Authority (EFSA) has issued an opinion asserting that no health-based guidance value for humans can be established for these congeners because simultaneous exposure to non-dioxin-like PCBs and dioxin-like compounds hampers The interpretation of The results of The toxicological and epidemiological studies [35]. Consequently, uncertainty remains on how to interpret The data in terms of public health. However, The tolerable daily intake of $10 \mathrm{ng} \mathrm{kg}^{-1}$ bw day ${ }^{-1}$ formerly set at The national level in Netherland and then adopted also by The French Agency Food Safety (AFSSA) [52] and Norwegian Scientific Committee for Food Safety [53] can be of help as a guidance value. In our case, based on The mean ndl-PCB concentration of $84.2 \mathrm{ng} \mathrm{g}^{-1}$ wet weight, The dietary exposure was estimated at $14.6 \mathrm{ng} \mathrm{kg}^{-1} \mathrm{bw} \mathrm{day}^{-1}$, which was higher than The limit value reported above. This finding might be of particular concern considering that The recommended value set 
by Netherland refers not only to The indicator PCBs, but to The whole non-dioxin-like PCB congeners. In addition, humans exposed to a mixture of chemicals and The interaction with other toxicants may cause additive and synergic effects. It is The case of PCBs whose toxic action may be potentiated by mercury. In fact, it has been found that there is a positive relationship between $\mathrm{Hg}$ and PCB concentrations in fish, fish consumption by pregnant women, and deficit neurobehavioral development in children [54]. However, it is important to underline that different sources of uncertainties may affect The intake assessment. The expression of The results with non-detected equal to zero can cause an underestimation in The TEQ value and The FAO STAT database not reporting The data referring to tuna consumption but to The whole category of pelagic fish may lead to an overestimation of The exposure. Other uncertainties may be linked to food preparation, which may cause a under- or overestimation, due to lipid losses or further contamination in relation to The cooking mode (boiling, roasting, baking, grilling).

\section{Conclusions}

The scientific literature has indicated that The levels of these synthetic chemicals in The environment appear to have stalled in recent years [55,56], implying a consequent reduction in The dietary intake of PCBs and PCDD/Fs [57]. This finding surely reflects The entry in force of numerous legislative measures, for example, on emission of PCDDs, phasing out of PCBs, as well as The maximum tolerated levels in food, and so forth. In our study, The PCDD/F and PCB contents do not exceed The hygienic standards relative to marketing, while The ndl-PCB concentrations in many cases are higher than The maximum level established by EU [13]. The estimated dietary intakes of PCBs and PCDD/Fs are below The toxicological reference values set by The various international bodies. Nevertheless, The risk assessment presents a different scenario. The quantity of tuna safe to be consumed monthly, without causing chronic effects and carcinogenic risk because of The PCB content is moderate, while relative to PCDD/Fs, caution is recommended, especially for people from categories that are mostly exposed (fishermen and their families) or particularly sensitive (pregnant women, children, and elderly people). On The other hand, also for The six ndl-PCBs, The estimated intake is above The value set at The national level for non-dioxin-like PCBs in some countries, corroborating The opinion that hazards associated with consumption of this species cannot be ignored. As a final conclusion, although The decline in The human dietary exposure to these xenobiotic chemicals is a fact, high-trophic fish, especially from The Mediterranean Sea [6], continue to accumulate large amounts of chemicals from The environment polluted during The previous decades. Taking into account The relevant nutritional contribution that fish give to The diet and, on The other hand, that The consumption of contaminated fish is The major pathway of human exposure to these compounds, caution is suggested in tuna consumption and an active and frequent surveillance of The chemical quality of this valuable fishery resource is recommended.

Author Contributions: Conceptualization, M.M.S. and G.B.; Methodology, M.M. and A.S.; Software, R.S. and N.Q.; Validation, A.S.; Formal Analysis, R.S. and R.G.; Data Curation, A.S.; Writing-Original Draft Preparation, M.M.S. and G.B.; Writing-Review, M.M.S.; Editing, A.S.; Supervision, M.M.S. and G.B.

Conflicts of Interest: The authors declare no conflict of interest.

\section{References}

1. Nakatani, T.; Yamamoto, A.; Ogaki, S. A survey of dietary intake of polychlorinated dibenzo-p-dioxins, polychlorinated dibenzofurans, and dioxin-like coplanar polychlorinated biphenyls from food during 2000-2002 in Osaka City, Japan. Arch. Environ. Contam. Toxicol. 2011, 60, 543-555. [CrossRef] [PubMed]

2. International Agency for Research on Cancer (IARC). EPA's Reanalysis of Key Issues Related to Dioxin Toxicity and Response to NAS Comments; IARC Monographs on The Evaluation of Carcinogenic Risks to Humans: Lyon, France, 2009; Volume 100F, pp. 1-690. ISBN 9789283213239.

3. International Agency for Research on Cancer (IARC). Polychlorinated Biphenyls and Polybrominated Biphenyls; IARC Monographs on The Evaluation of Carcinogenic Risks to Humans: Lyon, France, 2013; Volume 107, pp. 1-510. ISBN 9789283201731. 
4. Storelli, M.M.; Dambrosio, A.; Storelli, A.; Barone, G.; Ioanna, F.; Normanno, G. Levels of polychlorinated biphenyls (PCBs) in marine gastropod Hexaplex trunculus: Compliance with European Union legislation. J. Food Compos. Anal. 2014, 36, 35-39. [CrossRef]

5. Renzi, M.; Cau, A.; Bianchi, N.; Focardi, S.E. Levels of mercury and polychlorobiphenyls in bluefin tuna from The Western Mediterranean Sea: A food safety issue? J. Environ. Prot. 2014, 5, 106-113. [CrossRef]

6. Chiesa, L.M.; Labella, G.F.; Panseri, S.; Pavlovic, R.; Bonacci, S.; Arioli, F. Distribution of persistent organic pollutants (POPs) in wild Bluefin tuna (Thunnus thynnus) from different FAO capture zones. Chemosphere 2016, 153, 162-169. [CrossRef] [PubMed]

7. Sprague, M.; Dick, J.R.; Medina, A.; Tocher, D.R.; Bell, J.G.; Mourente, G. Lipid and fatty acid composition, and persistent organic pollutant levels in tissues of migrating Atlantic bluefin tuna (Thunnus thynnus, L.) broodstock. Environ. Pollut. 2012, 171, 61-71. [CrossRef] [PubMed]

8. Ueno, D.; Iwata, H.; Tanabe, S.; Ikeda, K.; Koyama, J.; Yamada, H. Specific accumulation of persistent organochlorines in bluefin tuna collected from Japanese coastal waters. Mar. Pollut. Bull. 2002, 45, 254-261. [CrossRef]

9. Corsolini, S.; Ademollo, N.; Romeo, T.; Greco, S.; Focardi, S. Persistent organic pollutants in edible fish: A human and environmental health problem. Microchem. J. 2005, 79, 115-123. [CrossRef]

10. Vizzini, S.; Tramati, C.; Mazzola, A. Comparison of stable isotope composition and inorganic and organic contaminant levels in wild and farmed bluefin tuna, Thunnus thynnus, in The Mediterranean Sea. Chemosphere 2010, 78, 1236-1243. [CrossRef] [PubMed]

11. Nicklisch, S.C.T.; Bonito, L.T.; Sandin, S.; Hamdoun, A. Geographic differences in persistent organic pollutant levels of yellowfin tuna. Environ. Health Perspect. 2017, 125, 067014. [CrossRef] [PubMed]

12. Barone, G.; Giacominelli-Stuffler, R.; Garofalo, R.; Castiglia, D.; Storelli, M.M. PCBs and PCDD/PCDFs in fishery products: Occurrence, congener profile and compliance with European Union legislation. Food Chem. Toxicol. 2014, 74, 200-205. [CrossRef] [PubMed]

13. Official Journal of The European Union. Commission regulation (EU) no. 1259/2011 of 2 December 2011 amending Regulation (EC) no. 1881/2006 setting maximum levels for certain contaminants in foodstuffs as regards dioxin-like PCBs and non-dioxin-like PCBs. OJEU 2011, 320, 18-23.

14. World Health Organization (WHO). Assessment of The health risk of dioxins: Re-evaluation of The tolerable daily intake (TDI). In Proceedings of The WHO Consultation, Geneva, Switzerland, 25-29 May 1998; Volume 17.

15. Joint FAO/WHO Expert Committee on Food Additives (JECFA). Evaluation of Certain Food Additives and Contaminants; Fifty-Seventh Report of The Joint FAO/WHO Expert Committee on Foods Additives; WHO Technical Report Series; WHO: Geneva, Switerland, 2002; Volume 909, pp. 1-186.

16. Official Journal of The European Union. Commission regulation (EU) no. 1881/2006 of 19 December 2006 setting maximum levels for certain contaminants in foodstuffs. OJEU 2006, 364, 5-24.

17. Official Journal of The European Union. Commission regulation (EU) no. 644/2017 laying down methods of sampling and analysis for The control of levels of dioxins, dioxin-like PCBs and non-dioxin-like PCBs in certain foodstuffs and repealing Regulation (EU) No 589/2014. OJEU 2017, 92, 9-33.

18. Rodríguez-Roda, J. Biología del atún, Thunnus thynnus (L.), de la costa sudatlántica de España. Inv. Pesq. 1964, 25, 33-146.

19. Corriero, A.; Karakulak, S.; Santamaria, N.; Deflorio, M.; Spedicato, D.; Addis, P.; Desantis, S.; Cirillo, F.; Fenech-Farrugia, A.; Vassallo-Agius, R.; et al. Size and age at sexual maturity of female bluefin tuna (Thunnys thynnus L. 1758) from The Mediterranean Sea. J. Appl. Ichthyol. 2005, 21, 483-486. [CrossRef]

20. Ricker, W.E. Growth rates and models. In Fish Physiology; Hoar, W.S., Randall, D.J., Brett, J.R., Eds.; Academic Press: New York, NY, USA, 1979; pp. 677-743. ISBN 9780080585253.

21. Storelli, M.M.; Barone, G.; Storelli, A.; Marcotrigiano, G.O. Levels and congener profiles of PCBs and PCDD/Fs in blue shark (Prionace glauca) liver from The South-Eastern Mediterranean Sea (Italy). Chemosphere 2011, 82, 37-42. [CrossRef] [PubMed]

22. Food and Agriculture Organization (FAO). FAOSTAT Food Supply: Livestock and Fish Primary Equivalent. 2013. Available online: http://faostat.fao.org/site/6107DesktopDefault.aspx?PageID=610 (accessed on 15 October 2017).

23. Van den Berg, M.; Birnbaum, L.; Denison, M.; De Vito, M.; Farland, W.; Feeley, M.; Fiedler, H.; Hakansson, H.; Hanberg, A.; Hawas, L.; et al. The 2005 World Health Organization reevaluation of human and mammalian 
toxic equivalency factors for dioxins and dioxin-like compounds. Toxicol. Sci. 2006, 93, 223-241. [CrossRef] [PubMed]

24. United States Environmental Protection Agency (US EPA). Guidance for Assessing Chemical Contaminant Data for Use in Fish Advisories, 3rd ed.; Volume 2: Risk Assessment and Fish Consumption Limits; US EPA: Washington, DC, USA, 2000; 383p.

25. Diaz, C.; Galindo, L.; Garcia Montelongo, F. Distribution of metals in some fishes from Santa Cruz de Tenerife, Canary Islands. Bull. Environ. Contam. Toxicol. 1994, 52, 347-381. [CrossRef]

26. Munschy, C.; Bodin, N.; Potier, M.; Héas-Moisan, K.; Pollono, C.; Degroote, M.; West, W.; Hollanda, S.J.; Puech, A.; Bourjea, J.; et al. Persistent organic pollutants in albacore tuna (Thunnus alalunga) from Reunion Island (Southwest Indian Ocean) and South Africa in relation to biological and trophic characteristics. Environ. Res. 2016, 148, 196-206. [CrossRef] [PubMed]

27. Corsolini, S.; Sara, G.; Borghesi, N.; Focardi, S. HCB, p, $p^{\prime}$-DDE and PCB Ontogenetic Transfer and Magnification in Bluefin Tuna (Thunnus thynnus) from The Mediterranean Sea. Environ. Sci. Technol. 2007, 41, 4227-4233. [CrossRef] [PubMed]

28. Torres, J.P.M.; Munschy, C.; Héas-Moisan, K.; Potier, M.; Ménard, F.; Bodin, N. Organohalogen compounds in yellowfin tuna (Thunnus albacares) from The western Indian Ocean. Organohal. Compd. 2009, 71, 1915-1920.

29. Moon, H.B.; Kim, H.S.; Choi, M.; Yu, J.; Choi, H.G. Human health risk of poly chlorinated biphenyls and organochlorine pesticides resulting from seafood consumption in South Korea, 2005-2007. Food Chem. Toxicol. 2009, 47, 1819-1825. [CrossRef] [PubMed]

30. Storelli, M.M.; Barone, G.; Perrone, V.G.; Giacominelli-Stuffler, R. Polychlorinated biphenyls (PCBs), dioxins and furans (PCDD/Fs): Occurrence in fishery products and dietary intake. Food Chem. 2011, 127, 1648-1652. [CrossRef]

31. Storelli, M.M.; Barone, G.; Perrone, V.G.; Giacominelli-Stuffler, R.; Marcotrigiano, G.O. Contamination by polychlorinated biphenyls (PCBs) in striped dolphins (Stenella coeruleoalba) from The Southeastern Mediterranean Sea. Environ. Monit. Assess. 2011, 184, 5797-5805. [CrossRef] [PubMed]

32. Storelli, M.M.; Casalino, E.; Barone, G.; Marcotrigiano, G.O. Persistent organic pollutants (PCBs and DDTs) in small size specimens of bluefin tuna (Thunnus thynnus) from The Mediterranean Sea (Ionian Sea). Environ. Int. 2008, 34, 509-513. [CrossRef] [PubMed]

33. Nakata, H.; Sakai, Y.; Miyawaki, T. Growth-dependent and species-specific accumulation of polychlorinated biphenyls (PCBs) in tidal flat organisms collected from The Ariake Sea, Japan. Arch. Environ. Contam. Toxicol. 2002, 42, 222-228. [CrossRef] [PubMed]

34. Baptista, J.; Pato, P.; Duarte, A.C.; Pardal, M.A. Organochlorine contaminants in different tissues from Platichthys flesus (Pisces, Pleuronectidea). Chemosphere 2013, 93, 1632-1638. [CrossRef] [PubMed]

35. European Food Safety Authority (EFSA). Opinion of The scientific panel on contaminants in The food chain on a request from The commission related to The presence of non dioxin-like polychlorinated biphenyls (PCB) in feed and food. EFSA J. 2005, 284, 1-137.

36. Squadrone, S.; Favaro, R.; Prearo, M.; Vivaldi, B.; Brizio, P.; Abete, M.C. NDL-PCBs in muscle of The European catfish (Silurus glanis): An alert from Italian rivers. Chemosphere 2013, 93, 521-525. [CrossRef] [PubMed]

37. McFarland, V.A.; Clarke, J.U. Environmental occurrence, abundance, and potential toxicity of polychlorinated biphenyl congeners: Considerations for a congener-specific analysis. Environ. Health Perspect. 1989, 81, 225-239. [CrossRef] [PubMed]

38. Mezzetta, S.; Cirlini, M.; Ceron, P.; Tecleanu, A.; Caligiani, A.; Palla, G.; Sansebastiano, G.E. Concentration of DL-PCBs in fish from market of Parma city (north Italy): Estimated human intake. Chemosphere 2011, 82, 1293-1300. [CrossRef] [PubMed]

39. Riget, F.; Vikelsoe, J.; Dietz, R. Levels and temporal trends of PCDD/PCDFs and non-ortho PCBs in ringed seals from East Greenland. Mar. Pollut. Bull. 2005, 50, 1523-1529. [CrossRef] [PubMed]

40. Van Leeuwen, S.P.J.; Leonards, P.E.G.; Traag, W.A.; Hoogenboom, L.A.P.; de Boer, J. Polychlorinated dibenzo- $p$-dioxins, dibenzofurans and biphenyls in fish from The Netherlands: Concentrations, profiles and comparison with DR CALUX ${ }^{\circledR}$ bioassay results. Anal. Bioanal. Chem. 2007, 389, 321-333. [CrossRef] [PubMed]

41. Strid, A.; Jörundsdóttir, H.; Päpke, O.; Svavarsson, J.; Bergman, Å. Dioxins and PCBs in Greenland shark (Somniosus microcephalus) from The North-East Atlantic. Mar. Pollut. Bull. 2007, 54, 1514-1522. [CrossRef] [PubMed] 
42. Leong, Y.-H.; Gan, C.-Y.; Majid, M.I.A. Dioxin-like Polychlorinated biphenyls, polychlorinated dibenzo-p-dioxins, and polychlorinated dibenzofurans in seafood samples from Malaysia: Estimated human intake and associated risks. Arch. Environ. Contam. Toxicol. 2014, 67, 21-28. [CrossRef] [PubMed]

43. Tilson, H.A.; Kodavanti, P.R.; Mundy, W.R.; Bushnell, P.J. Neurotoxicity of environmental chemicals and their mechanism of action. Toxicol. Lett. 1998, 102-103, 631-635. [CrossRef]

44. Brown, A.P.; Olivero-Verbel, J.; Holdan, W.L.; Ganey, P.E. Neutrophil activation by polychlorinated biphenyls: Structure-activity relationship. Toxicol. Sci. 1998, 46, 308-316. [PubMed]

45. Brunelli, L.; Llansola, M.; Felipo, V.; Campagna, R.; Airoldi, L.; De Paola, M.; Fanelli, R.; Mariani, A.; Mazzoletti, M.; Pastorelli, R. Insight into The neuroproteomics effects of The food-contaminant non-dioxin like polychlorinated biphenyls. J. Proteom. 2012, 75, 2417-2430. [CrossRef] [PubMed]

46. Cimenci, O.; Vandevijvere, S.; Coscinny, S.; Van den Berg, M.A.; Hanot, V.; Vinkx, C.; Bolle, F.; Van Loco, J. Dietary exposure of The Belgian adult population to non-dioxin-like PCBs. Food Chem. Toxicol. 2013, 59, 670-679. [CrossRef] [PubMed]

47. Engler, M.M.; Engler, M.B. Omega-3 fatty acids: Role in cardiovascular health and disease. J. Cardiovasc. Nurs. 2006, 21, 17-24. [CrossRef] [PubMed]

48. American Heart Association Nutrition Committee (AHANC). Diet and lifestyle recommendation revision 2006: A scientific statement from The American Heart Association Nutrition Committee. Circulation 2006, 114, 82-96.

49. United States Environmental Protection Agency (US EPA). Polychlorinated Biphenyls (PCBs) TEACH Chemical Summary. 2007. Available online: http://www.epa.gov/teach/chem_summ/PCB_ summary100809.pdf (accessed on 15 October 2017).

50. Marin, S.; Villalba, P.; Diaz-Ferrero, J.; Font, G.; Yusa, V. Congener profile, occurrence and estimated dietary intake of dioxins and dioxin-like PCBs in foods marketed in The Region of Valencia (Spain). Chemosphere 2011, 82, 1253-1261. [CrossRef] [PubMed]

51. United States Environmental Protection Agency (US EPA). EPA's Reanalysis of Key Issues Related to Dioxin Toxicity and Response to NAS Comments, Volume 1. In Support of Summary Information on The Integrated Risk Information System (IRIS); 2012. Available online: https:/ /cfpub.epa.gov/ncea/iris/iris_documents / documents/supdocs/dioxinv1sup.pdf (accessed on 3 April 2018).

52. Agence Française de Sécurité Sanitaire des Aliments (AFSSA). Opinion of The French Food Safety Agency on The Establishment of Relevant Maximum Levels for Non-Dioxin-Like Polychlorobiphenyls (NDL-PCB) in Some Foodstuffs; Maisons-Alfort 2007, 2006-SA-0305; AFSSA: Paris, France, 2007; 27p.

53. Norwegian Scientific Committee for Food Safety (VKM). Opinion of The Panel on Contaminants of The Norwegian Scientific Committee for Food Safety; Risk Assessment of Non-dioxin-like PCBs in Norwegian Food; VKM Report; VKM: Oslo, Norway, 2008; Volume 14, 21p.

54. Schantz, S.L.; Widholm, J.J.; Rice, D.C. Effects of PCB exposure on neuropsychological function in children. Environ. Health Perspect. 2003, 111, 357-376. [CrossRef] [PubMed]

55. Law, R.J. An overview of time trends inorganic contaminant concentrations in marine mammals: Going up or down? Mar. Pollut. Bull. 2014, 82, 7-10. [CrossRef] [PubMed]

56. Riget, F.; Vorkamp, K.; Bossi, R.; Sonne, C.; Letcher, R.J.; Dietz, R. Twenty years of monitoring of persistent organic pollutants in Greenland biota. A review. Environ. Pollut. 2016, 217, 114-123. [CrossRef] [PubMed]

57. Llobet, J.M.; Martì-Cid, R.; Perellò, G.; Domingo, J.L. Human dietary exposure to PCDD/PCDFs and PCBs in Catalonia, Spain. Organohal. Compd. 2008, 70, 1534-1537.

(C) 2018 by the authors. Licensee MDPI, Basel, Switzerland. This article is an open access article distributed under the terms and conditions of the Creative Commons Attribution (CC BY) license (http://creativecommons.org/licenses/by/4.0/). 